\title{
Studi Komparatif Balita Stunting di Perkotaan dan Pedesaan Berdasarkan Karakteristik Keluarga
}

\author{
Evalina Manurung ${ }^{(1)}$, Ribka Flora Panjaitan ${ }^{(2)}$ \\ Institut Kesehatan Deli Husada Deli Tua \\ Corresponding author : evalinamanurung85@gmail.com \\ evalinamanurung85@gmail.com (1), Ribka.florapanjaitan@gmail.com (2)
}

\begin{abstract}
ABSTRAK
Kejadian balita pendek atau biasa disebut dengan stunting merupakan salah satu masalah gizi yang dialami oleh balita di dunia saat ini. Pada tahun $201722,2 \%$ atau sekitar 150,8 juta balita di dunia mengalami stunting. Masalah stunting dampak dari defisiensi nutrien selama seribu hari pertama kehidupan yang menimbulkan gangguan perkembangan fisik anak yang irreversible, sehingga menyebabkan penurunan kemampuan kognitif dan motorik serta penurunan performa kerja. Anak stunting memiliki rerata skor Intelligence Quotient (IQ) sebelas poin lebih rendah dibandingkan rerata skor IQ pada anak normal. Gangguan tumbuh kembang pada anak akibat kekurangan gizi bila tidak mendapatkan intervensi sejak dini akan berlanjut hingga dewasa.Penelitian ini bertujuan untuk menganalisis perbedaan karakteristik Keluarga dengan balita stunting di Pedesaan dan Perkotaan. Penelitian merupakan studi Observasional dengan desain kasus kontrol melalui pendekatan retrospektif terhadap 45 balita stunting di Perkotaan pada kelompok kasus dan 45 balita stunting di Pedesaan pada kelompok kontrol. Pengumpulan data akan dilakukan melalui observasi dan wawancara yang berpedoman pada kuesioner.
\end{abstract}

Kata Kunci : Balita, Stunting, Komparatif, Karakteristik Keluarga

\begin{abstract}
The incidence of short children or commonly known as stunting is one of the nutritional problems experienced by toddlers in the world today. In $201722.2 \%$ or around 150.8 million children under five in the world were stunted. The problem of stunting is the impact of nutrient deficiency during the first thousand days of life which causes irreversible physical development problems in children, causing a decrease in cognitive and motor skills and a decrease in work performance. Stunted children had a mean Intelligence Quotient (IQ) score, eleven points lower than the average IQ score in normal children. Growth and development disorders in children due to malnutrition if they do not get intervention from an early age will continue into adulthood. This study aims to analyze differences in the characteristics of families with stunting children in rural and urban areas. This research is an observational study with a case control design through a retrospective approach to 45 urban stunting toddlers in the case group and 45 stunting children in rural areas in the control group. Data collection will be done through observation and interviews based on questionnaires.
\end{abstract}

Keywords : Toddlers, Stunting, Comparability, Family Characteristis 
Manurung E, Flora Panjaitan R: Studi Komparatif Balita Stunting di Perkotaan dan Pedesaan Berdasarkan Karakteristik Keluarga

\section{PENDAHULUAN}

\section{Latar Belakang}

Kejadian balita stunting (pendek) merupakan masalah gizi utama yang dihadapi Indonesia. Berdasarkan data Pemantauan Status Gizi (PSG) selama tiga tahun terakhir, pendek memiliki prevalensi tertinggi dibandingkan dengan masalah gizi lainnya seperti gizi kurang, kurus, dan gemuk. Prevalensi balita pendek mengalami peningkatan dari tahun 2016 yaitu 27,5\% menjadi 29,6\% pada tahun 2017. Hasil Riset Kesehatan Dasar (Riskesdas) tahun 2010 menunjukkan prevalensi balita pendek di Indonesia sebesar 35,6\%. Pada tahun 2013 menjadi 37,2\%.Survei PSG diselenggarakan sebagai monitoring dan evaluasi kegiatan dan capaian program. Berdasarkan hasil PSG tahun 2015, prevalensi balita pendek di Indonesia adalah 29\%. Angka ini mengalami penurunan pada tahun 2016 menjadi 27,5\%. Namun prevalensi balita pendek kembali meningkat menjadi 29,6\% pada tahun 2017. Kondisi kesehatan dan gizi ibu sebelum dan saat kehamilan serta setelah persalinan mempengaruhi pertumbuhan janin dan risiko terjadinya stunting. Faktor lainnya pada ibu yang mempengaruhi adalah postur tubuh ibu (pendek), jarak kehamilan yang terlalu dekat, ibu yang masih remaja, serta asupan nutrisi yang kurang pada saat kehamilan. Menurut Peraturan Menteri Kesehatan Nomor 97 Tahun 2014 tentang Pelayanan Kesehatan Masa sebelum Hamil, Masa Hamil, Persalinan, dan Masa sesudah Melahirkan, Penyelenggaraan Pelayanan Kontrasepsi, serta Pelayanan Kesehatan Seksual, faktor-faktor yang memperberat keadaan ibu hamil adalah terlalu muda, terlalu tua, terlalu sering melahirkan, dan terlalu dekat jarak kelahiran. Usia kehamilan ibu yang terlalu muda (di bawah 20 tahun) berisiko melahirkan bayi dengan berat lahir rendah (BBLR). Bayi BBLR mempengaruhi sekitar $20 \%$ dari terjadinya stunting. Prevalensi stunting di Indonesia menempati peringkat kelima terbesar di dunia. Data Riset kesehatan dasar (Riskesdas) tahun 2013 menunjukkan prevalensi stunting dalam lingkup nasional sebesar 37,2 persen, terdiri dari prevalensi pendek sebesar 18,0 persen dan sangat pendek sebesar 19,2 persen. Stunting dianggap sebagai masalah kesehatan masyarakat yang berat bila prevalensi stunting berada pada rentang 30-39 persen. Hal ini menunjukkan bahwa Indonesia sedang mengalami masalah kesehatan masyarakat yang berat dalam kasus balita stunting. Stunting pada balita perlu mendapatkan perhatian khusus karena dapat menyebabkan terhambatnya pertumbuhan fisik, perkembangan mental dan status kesehatan pada anak. Anak yang mengalami stunting berkaitan dengan prestasi di sekolah yang buruk, tingkat pendidikan yang rendah dan pendapatan yang rendah saat dewasa. Anak yang mengalami stunting memiliki kemungkinan lebih besar tumbuh menjadi individu dewasa yang tidak sehat dan miskin. Stunting pada anak juga berhubungan dengan peningkatan kerentanan anak terhadap penyakit, baik penyakit menular maupun Penyakit Tidak Menular (PTM) serta peningkatan risiko overweight dan obesitas. Keadaan overweight dan obesitas jangka panjang dapat meningkatkan risiko penyakit degeneratif. Menurut Amosu et al. (2011) tingginya masalah gizi dipengaruhi berbagai faktor yang saling berinteraksi, seperti kemisikinan, pendidikan, ketersediaan pangan di tingkat rumah tangga, yang akan berdampak terhadap rendahnya pendapatan keluarga. Handayani et al. (2013), menyatakan bahwa terdapat perbedaan status gizi menurut indeks masa tubuh berdasarkan daerah tempat sekolah yaitu antara daerah pedesaan dengan perkotaan, selain itu juga disebabkan oleh keadaan gizi dan kesehatan umum serta status sosial ekonomi. Faktor besarnya jumlah anggota keluarga serta daerah tinggal berdampak terhadap masalah gizi, menurut Labada et al. (2016) jumlah anggota keluarga berdampak terhadap status gizi balita yang tidak normal yaitu sebesar $26,8 \%$. 
Manurung E, Flora Panjaitan R: Studi Komparatif Balita Stunting di Perkotaan dan Pedesaan Berdasarkan Karakteristik Keluarga

\section{Perumusan Masalah}

Berdasarkan latar belakang di atas dapat dirumuskan masalah dari penelitian adalah bagaimana perbedaan karakteristik Keluarga di Pedesaan dan Perkotaan yang menjadi faktor yang berhubungan dengan kejadian stunting pada balita.

\section{Tujuan Penelitian}

Penelitian ini bertujuan yaitu :

1. Untuk menganalisis perbedaan Status Gizi Ibu dengan balita stunting di Perkotaan dan Pedesaan.

2. Untuk menganalisis perbedaan Status Pekerjaan Ibu dengan balita stunting di Perkotaan dan Pedesaan.

3. Untuk menganalisis perbedaan Status Pendidikan Ibu dengan balita stunting di Perkotaan dan Pedesaan.

4. Untuk menganalisis perbedaan Jarak melahirkan Ibu dengan balita stunting di Perkotaan dan Pedesaan.

5. Untuk menganalisis perbedaan Satus Paritas Ibu dengan balita stunting di Perkotaan dan Pedesaan.

\section{Manfaat Penelitian}

Bermanfaat sebagai sumber informasi mengenai referensi untuk mengetahui perbandingan masalah stunting pada balita berdasarkan karakteristik keluarga dan status tempat tinggal. variabel-variabel penelitian yang sejalan dengan roadmap Kesehatan Ibu dan Anak.

\section{METODE PENELITIAN \\ Rancangan Penelitian}

Rancangan penelitian yang akan digunakan adalah studi Observasional dengan desain kasus kontrol melalui pendekatan retrospektif terhadap 45 anak balita usia 24-59 bulan di Perkotaan pada kelompok kasus dan 45 anak balita usia 24-59 bulan pada kelompok kontrol yang bertujuan untuk menganalisis perbedaan karakteristik keluarga dengan balita stunting di Perkotaan dan Pedesaan.

\section{Lokasi Penelitian}

Penelitian pada kelompok kasus (Perkotaan) akan dilakukan di Kecamatan Medan Amplas sedangkan penelitian pada kelompok kontrol (Pedesaan) akan dilakukan di Desa Namorambe, Kecamatan Namorambe.

\section{Populasi dan Sampel}

Populasi kasus dalam penelitian ini adalah seluruh anak stunting usia 24-59 bulan yang bertempat tinggal di Kecamatan Medan Amplas dan populasi kontrol adalah seluruh anak stunting usia 24-59 bulan yang bertempat tinggal di Desa Namorambe, Kecamatan Namorambe.

Pemilihan sampel dalam penelitian ini menggunakan kriteria Inklusi sebagai berikut:

1. Orang tua bersedia berpartisipasi dalam penelitian

2. Memiliki balita stunting usia 24-59 bulan

Besar sampel dalam penelitian ditetapkan berdasarkan rumus kasus kontrol dengan populasi yang tidak diketahui yang diperoleh dengan rumus (Lameshow) Berdasarkan perhitungan di atas diperoleh sampel minimal sebanyak 45 kasus dan 45 kontrol. Metode penarikan sampel yang digunakan adalah consecutive sampling, anak balita stunting usia 24-59 bulan yang memenuhi kriteria inklusi dimasukkan dalam penelitian sampai jumlah subjek yang diperlukan dipenuhi. 
Manurung E, Flora Panjaitan R: Studi Komparatif Balita Stunting di Perkotaan dan Pedesaan Berdasarkan Karakteristik Keluarga

\section{Metode Pengumpulan Data}

Data primer Data yang di peroleh langsung dari responden melalui pengukuran status gizi Ibu dan wawancara dengan menggunakan instrumen (kuesioner). Data sekunder berupa data keluarga yang memiliki balita stunting usia 24-59 bulan yang berdomisili di Kecamatan Medan Amplas dan Desa Namorambe, Kecamatan Namorambe yang diperoleh dari RSU.Sembiring, Bidan Desa dan Puskesmas Namorambe.

\section{HASIL PENELITIAN}

Tabel 1. Hubungan Pendapatan Keluarga dengan kejadian stunting

\begin{tabular}{|c|c|c|c|c|c|}
\hline & & \multicolumn{2}{|c|}{ PendapatanKeluarga } & \multirow[b]{2}{*}{ Total } & \multirow[b]{2}{*}{ p-value } \\
\hline & & $>=\mathrm{UMP}$ & $<\mathrm{UMP}$ & & \\
\hline \multirow[t]{4}{*}{ Responden } & \multirow[t]{2}{*}{ Perkotaan } & 37 & 8 & 45 & \multirow{6}{*}{0,036} \\
\hline & & $41.1 \%$ & $8.9 \%$ & $50.0 \%$ & \\
\hline & \multirow[t]{2}{*}{ Pedesaan } & 27 & 18 & 45 & \\
\hline & & $30.0 \%$ & $20.0 \%$ & $50.0 \%$ & \\
\hline \multirow{2}{*}{\multicolumn{2}{|c|}{ Total }} & 64 & 26 & 90 & \\
\hline & & $71.1 \%$ & $28.9 \%$ & $100.0 \%$ & \\
\hline
\end{tabular}

Hasil penelitian pada tabel 1 menunjukkan bahwa ada hubungan secara statistik antara pendapatan keluarga dengan kejadian stunting, dilihat dari nilai p-value yaitu 0,036 <0,05.

Tabel 2. Hubungan Pengasuh Utama dengan kejadian stunting

\begin{tabular}{|c|c|c|c|c|c|c|}
\hline & & \multicolumn{3}{|c|}{ PengasuhUtama } & \multirow[b]{2}{*}{ Total } & \multirow[b]{2}{*}{ p-value } \\
\hline & & Keluarga Inti & Kerabat Dekat & Pengasuh & & \\
\hline \multirow[t]{4}{*}{ Responden } & \multirow[t]{2}{*}{ Perkotaan } & 18 & 11 & 16 & 45 & \multirow{6}{*}{0,011} \\
\hline & & $20.0 \%$ & $12.2 \%$ & $17.8 \%$ & $50.0 \%$ & \\
\hline & \multirow[t]{2}{*}{ Pedesaan } & 11 & 25 & 9 & 45 & \\
\hline & & $12.2 \%$ & $27.8 \%$ & $10.0 \%$ & $50.0 \%$ & \\
\hline \multirow{2}{*}{\multicolumn{2}{|c|}{ Total }} & 29 & 36 & 25 & 90 & \\
\hline & & $32.2 \%$ & $40.0 \%$ & $27.8 \%$ & $100.0 \%$ & \\
\hline
\end{tabular}

Hasil penelitian pada tabel 2 menunjukkan bahwa ada hubungan secara statistik antara Pengasuh Utama dengan kejadian stunting, dilihat dari nilai $p$-value yaitu $0,011<0,05$.

Tabel 3. Hubungan Jumlah Anggota Keluarga dengan kejadian stunting

\begin{tabular}{|c|c|c|c|c|c|c|}
\hline & & \multicolumn{3}{|c|}{ JumlahAnggotaKeluarga } & \multirow[b]{2}{*}{ Total } & \multirow[b]{2}{*}{$\mathrm{p}$-value } \\
\hline & & 3 orang & 4 orang & $>4$ orang & & \\
\hline \multirow[t]{4}{*}{ Responden } & \multirow[t]{2}{*}{ Perkotaan } & 15 & 14 & 16 & 45 & \multirow{6}{*}{0,129} \\
\hline & & $16.7 \%$ & $15.6 \%$ & $17.8 \%$ & $50.0 \%$ & \\
\hline & \multirow[t]{2}{*}{ Pedesaan } & 16 & 21 & 8 & 45 & \\
\hline & & $17.8 \%$ & $23.3 \%$ & $8.9 \%$ & $50.0 \%$ & \\
\hline \multirow{2}{*}{\multicolumn{2}{|c|}{ Total }} & 31 & 35 & 24 & 90 & \\
\hline & & $34.4 \%$ & $38.9 \%$ & $26.7 \%$ & $100.0 \%$ & \\
\hline
\end{tabular}


Manurung E, Flora Panjaitan R: Studi Komparatif Balita Stunting di Perkotaan dan Pedesaan Berdasarkan Karakteristik Keluarga

Hasil penelitian pada tabel 3 menunjukkan bahwa tidak ada hubungan secara statistik antara Jumlah anggota keluarga dengan kejadian stunting, dilihat dari nilai p-value yaitu 0,129 > 0,05 .

Tabel 4. Hubungan Paritas Ibu dengan kejadian stunting

\begin{tabular}{|c|c|c|c|c|c|}
\hline & & \multicolumn{2}{|l|}{ ParitasIbu } & \multirow[b]{2}{*}{ Total } & \multirow[b]{2}{*}{ p-value } \\
\hline & & Primigravida & Multigravida & & \\
\hline \multirow[t]{4}{*}{ Responden } & \multirow[t]{2}{*}{ Perkotaan } & 36 & 9 & 45 & \multirow{6}{*}{0,233} \\
\hline & & $40.0 \%$ & $10.0 \%$ & $50.0 \%$ & \\
\hline & \multirow[t]{2}{*}{ Pedesaan } & 30 & 15 & 45 & \\
\hline & & $33.3 \%$ & $16.7 \%$ & $50.0 \%$ & \\
\hline \multirow{2}{*}{\multicolumn{2}{|c|}{ Total }} & 66 & 24 & 90 & \\
\hline & & $73.3 \%$ & $26.7 \%$ & $100.0 \%$ & \\
\hline
\end{tabular}

Hasil penelitian pada tabel 4 menunjukkan bahwa tidak ada hubungan secara statistik antara Paritas Ibu dengan kejadian stunting, dilihat dari nilai p-value yaitu 0,233 > 0,05.

Tabel 5. Hubungan Jarak Melahirkan Ibu dengan kejadian stuntin

\begin{tabular}{|c|c|c|c|c|c|}
\hline & & \multicolumn{2}{|c|}{ Jarak Melahirkan } & \multirow[b]{2}{*}{ Total } & \multirow[b]{2}{*}{ p-value } \\
\hline & & Ideal & Kurang Ideal & & \\
\hline \multirow[t]{4}{*}{ Responden } & \multirow[t]{2}{*}{ Perkotaan } & 27 & 18 & 45 & \multirow{6}{*}{0,020} \\
\hline & & $30.0 \%$ & $20.0 \%$ & $50.0 \%$ & \\
\hline & \multirow[t]{2}{*}{ Pedesaan } & 15 & 30 & 45 & \\
\hline & & $16.7 \%$ & $33.3 \%$ & $50.0 \%$ & \\
\hline \multirow{2}{*}{\multicolumn{2}{|c|}{ Total }} & 42 & 48 & 90 & \\
\hline & & $46.7 \%$ & $53.3 \%$ & $100.0 \%$ & \\
\hline
\end{tabular}

Hasil penelitian pada tabel 5 menunjukkan bahwa ada hubungan secara statistik antara Jarak Melahirkan Ibu dengan kejadian stunting, dilihat dari nilai p-value yaitu 0,020<0,05.

Stunting (pendek) atau kurang gizi kronik adalah suatu bentuk lain dari kegagalan pertumbuhan. Kurang gizi kronik adalah keadaan yang sudah terjadi sejak lama, bukan seperti kurang gizi akut. Anak yang mengalami stunting sering terlihat memiliki badan normal yang proporsional, namun sebenarnya tinggi badannya lebih pendek dari tinggi badan normal yang dimiliki anak seusianya. Stunting merupakan proses kumulatif dan disebabkan oleh asupan zat-zat gizi yang tidak cukup atau penyakit infeksi yang berulang, atau kedua-duanya. Stunting dapat juga terjadi sebelum kelahiran dan disebabkan oleh asupan gizi yang sangat kurang saat masa kehamilan, pola asuh makan yang sangat kurang, rendahnya kualitas makanan sejalan dengan frekuensi infeksi sehingga dapat menghambat pertumbuhan Stunting merupakan suatu keadaan yang menunjukkan tinggi badan anak yang pendek menurut umurnya. Stunting atau terlalu pendek berdasarkan umur adalah tinggi badan yang berada di bawah minus dua standar deviasi (<-2SD). Stunting berkaitan dengan peningkatan risiko kesakitan dan kematian serta terhambatnya pertumbuhan kemampuan motorik dan mental. Dampak dari stunting yaitu penurunan fungsi kognitif, keterlambatan perkembangan, gangguan metabolik dan penurunan fungsi imun. 
Manurung E, Flora Panjaitan R: Studi Komparatif Balita Stunting di Perkotaan dan Pedesaan Berdasarkan Karakteristik Keluarga

\section{KESIMPULAN}

Berdasarkan hasil analisis dengan uji Chisquare dan Pearson Chisquare diketahui bahwa variabel yang berhubungan dengan Kejadian stunting yaitu variabel Pendapatan keluarga, Pengasuh Utama, Jarak Melahirkan Ibu, Status Pekerjaan Ibu dan Status Gizi Ibu. Sedangkan variabel yang tidak berhubungan dengan Kejadian stunting yaitu variabel Jumlah anggota keluarga, Paritas Ibu dan Pendidikan Ibu.

\section{DAFTAR PUSTAKA}

Badan Pusat Statistik. 2017. Statistik Kesejahteraan Rakyat Tahun 2017. Jakarta.

Kementerian Kesehatan RI. 2016. Buku Saku Pemantauan Status Gizi Tahun 2015. Jakarta. Kementerian Kesehatan RI. 2017. Buku Saku Pemantauan Status Gizi Tahun 2016. Jakarta. Kementerian Kesehatan RI. 2018. Buku Saku Pemantauan Status Gizi Tahun 2017. Jakarta. Trihono, Atmarita, Tjandrarini DH, Irawati A, Utami NH, Tejayanti T, et al. Pendek (stunting) di Indonesia, masalah dan solusinya. Jakarta: Lembaga Penerbit Balitbangkes; 2015.

Debora, N.C., 2011. Hubungan Riwayat Pola Asuh, Pola Makan, Asupan Zat Gizi terhadap Kejadian Stunting Pada Anak Usia 24-59 Bulan diKecamatan Biboki Utara Kabupaten Timor Tengah Utara Provinsi Nusa Tenggara Timur. Tesis. Yogyakarta : Universitas Gadjah Mada.

Amosu, A. M., Degun, A. M., Atulomah, N. O. S., \& Olanrewju, M. F. (2011). A study of the nutritional status of under- 5 children of low-income earners in a South-Western Nigerian community. Current Research Journal of Biological Sciences, 3(6), 578-585.

Handayani, M. S., Dwiriani, C. M., \& Riyadi, H. (2013). Hubungan komposisi tubuh dan status gizi dengan perkembangan seksual pada remaja putri di perkotaan dan perdesaan. Jurnal Gizi Dan Pangan, 8(3), 181-186.

Labada, A., Ismanto, A., \& Kundre, R. (2016). Hubungan karakteristik ibu dengan status gizi balita yang berkunjung di puskesmas Bahu Manado. eJournal Keperawatan, 4(1)

WHO, 2014. Trens : Underweight In Children in Global Health Observatory Available from : http://www.who.int/gho/mdg/poverty_hunger/underweight_text/en/. Diakses pada : 2014 ..

UNICEF, 2014. Stunting Among Children Aged Five or Younger: Inequality by Child's Sex. Available from : http://www.who.int/

\begin{tabular}{|l|l|l|l|}
\hline Accepted Date & Revised Date & Decided Date & Accepted to Publish \\
\hline 04 September 2020 & 10 September 2020 & 30 Oktober 2020 & Ya \\
\hline
\end{tabular}

